DOI: $10.31558 / 2308-1902.2018 .26 .2$

УДК 008:168.522

Валентина КРАСНІКОВА

кандидат філологічних наук, доцент, Донецький національний університет імені Василя Стуса

\title{
КУЛЬТУРОЛОГІЧНЕ ОСМИСЛЕННЯ МІФОЛОГЕМИ ДОЛІ В ПОЕЗІї ВАСИЛЯ СТУСА
}

Стаття містить спробу культурологічного аналізу міфологеми долі у творчості Василя Стуса. Приділено увагу визначенню семантики слова «доля». Схарактеризовано види, місце й роль феномена міфологеми долі в поезіях різних періодів. Порівняно розуміння долі у творчості Василя Стуса, у культурі загалом, фольклорі та поезії Тараса Шевченка.

Ключові слова: міф, міфологема, доля, недоля, щастя, нещастя, фатум, талан.

У наукових розвідках низки гуманітарних наук одним із ключових понять $є$ міф як втілення національної ментальності, первісний код архетипів, символів, смислів, уявлень, переконань. Наразі значно активізується дослідження міфу й міфологем художнього тексту, що розкриває специфіку не лише ідіостилю певних авторів, але й культури народу з урахуванням його міфологічних уявлень. У кінці XX - на початку XXI ст. міфокритичний метод стає основним у працях Г. Грабовича, Н. Глінки, А. Гурдуза, О. Забужко, В. Копиці, Т. Мейзерської, В. М’ястківської, В. Нарівської, Н. Ротової, Т. Саяпіної, Л. Хавкіної, І. Чернової та ін. У цей час помітна зміна акцентів і у стусознавстві: у кінці 1990-х років на зміну суто літературознавчій рецепції приходить комплексне й різнопланове вивчення тексту (праці таких дослідників, як Г.Гармаш, Т. Гундорова, М. Ільницький, С. Квіт, М. Коцюбинська, Г. Мовчанюк, І. Онікієнко, М. Павлишин, Л. Плющ, О. Рарицький). Методологічні можливості міфокритики щодо аналізу поезії В. Стуса переконливо доводить С. Саковець у дисертаційній роботі «Міфопоетика поезії Василя Стуса» [1], однак iï фундаментальна комплексна праця залишає можливості для розширення й доповнення запропонованого комплексу міфологем. Крім того, актуальним і перспективним видається застосування до цього комплексу культурологічного аналізу.

Mema cmammi - культурологічне осмислення місця й динаміки міфологеми долі у творчості В. Стуса - розкривається завдяки таким завданням: 
визначити семантику слова доля в науковій літературі та в розумінні В. Стуса; порівняти складові цієї міфологеми в українській культурі, фольклорі та творчості поета; простежити динаміку розвитку цієї міфологеми в різні періоди творчості поета.

Серед науковців немає одностайності у визначенні ключових понять дослідження. Тому коротко окреслимо деякі найважливіші 3 них. Ми послуговуємося поняттям міфологема, що виділене в культурології як «самостійний авторський образ, побудований на системі традиційних культурних і літературних парадигм, структура яких формується на давніх міфологічних підвалинах» [2, с. 12]. Поняття міфологема, образ та концепт Доля, на нашу думку, об'єднує те, що концепт Доля в українській культурі вербалізується такими іменниками, як доля, талан, фортуна, судьба (розм.). Семантика цього слова підтверджує уявлення українців про існування вищої сили, що наділяє людину щасливим або нещасливим життям. Ідеться про «перебіг подій», «напрям життєвого шляху людини», «обставини ії життя». Сутнісний рівень міфологеми Доля зумовлений відповіддю на питання про те, як діють сили на життя людини та що становлять собою ті сили, від яких залежить життя. Натомість поняття міфологема передбачає звернення до міфологічних сюжетів, сцен, образів, що характеризуються глобальністю та універсальністю. Термін «міфологема» має амбівалентну природу, зокрема це і міфологічний матеріал і грунт для створення нового матеріалу [3].

У традиційних культурах минулого й сьогодення доля $є$ одним 3 центральних понять, що пов'язане з ціннісними орієнтаціями особистості, иіi релігійними настановами й ментальністю, тому постає об'єктом аналізу в межах різних наук: філософії, релігієзнавства, літературознавства, лінгвістики, етики, психології, історії. «Своєрідне ставлення до долі - це характеристика будь-якої людини, ознака повсякденного змісту колективної свідомості, що знаходить своє втілення в багатьох символічних модусах культури», - наголошують філософи Т. Князевська та А. Огурцов [4, с. 177]. 
Поняття долі почало закладатися ще в період духовно-психологічного освоєння світу i відтворює складний динамічний процес оформлення міфопоетичної образності. «Ідея долі є найдавнішою екзистенцією людського життя, що виникла в той час, коли людина почала усвідомлювати залежність свого життя від природи, поведінки інших людей та вищих сил, які наділяють кожну людину щасливою або нещасливою долею. Згодом виникла антична міфологема долі. У міфології формувалися базові поняття культури, які розкривають внутрішній світ людини, ії світобачення, осмислення іiї місця та ролі в соціумі» $[5$, с. 226].

Доля у філософському розумінні пов'язана зі спрямованістю та зміною життєвого потоку, отже, споріднена з такими поняттями, як фатум, рок, необхідність, неволя, сум, совість та ін. На думку Г. Зіммеля, доля - це «такий стан людського життя, який під впливом зовнішніх подій різко змінює свою спрямованість» [6, с. 188]. Німецький філософ О. Шпенглер вважав спрямованість життя недостатньою для розуміння долі. За його розумінням, доля - це «внутрішня логіка самого життя, іï глибинна закономірність» $[7$, c.274]. У цих, на перший погляд, різних тлумаченнях, подібний смисл: поняттям «доля» ці філософи висловили залежність людини від сил, які мають суттєвий вплив на перебіг життя та його спрямованість. Суголосне цим визначення подане й у «Великому тлумачному словнику сучасної української мови»: «Доля - це перебіг подій, збіг обставин, напрям життєвого шляху, що ніби не залежить від бажання, волі людини; умови життя; життєвий шлях і те, що на ньому трапляється» $[8$, с. 43$]$.

Різні онтологічні універсалії, зокрема долі, формують ключові образи у творчості Т. Шевченка, І. Франка, Лесі Українки, О. Кобилянської, О. Олеся, Л. Костенко та ін. Розуміння долі в поезії В. Стуса водночас специфічне та певною мірою пов'язане 3 текстами цих відомих авторів. Згадаймо, наприклад, Шевченкові слова, які спливають у пам'яті під час читання стусівських рядків: «Дай Боже хоч біди якої, // коли ні краю ні коня // $і$ долі дай - та злої! злої! // - нехай донищує до пня» [9, с. 302]. 
Життєва доля В. Стуса, як зазначає I. Дзюба, позначається на його поезії. «Біографія і самонастановлення в нього невіддільні одне від одного. Рідкісна, трагічна неподільність поезії і долі» [10, с. 7]. Неодноразово поет звертається у своїй творчості до долі свого покоління, свого краю, до власної долі: «Наша доля вража // нас доріже - нашим ножем» [9, с. 75]. Отже, один із кодів стусівської міфологеми полягає в зіставленні й ототожненні своєї долі і долі свого народу, до того ж, трагічної долі. «Мій краю, матере моя, // мене ти вийми із неволі // або сподоб своєї долі» [9, с. 350], - пише він пізніше, уже намагаючись виокремити власну долю. I знову поєднує свою долю і долю рідної землі: «Той край навіки задубів. // Така бо доля наша чула» [9, с. 364].

Міфологема долі розкривається за допомогою інших споріднених чи протилежних понять. Так, традиційно В. Стус протиставляє міфологеми доля / недоля: «Пізнай свою недолю, // як тіні оступили», «Є недоля люта // і анічого більше вже нема», «Недоле, нишком догоряй - // і не кажи про те нікому», «Доріже без ножа розпроклятуща доля - // така мені недоля, така мені чужа», «І сниться сто твої подоб, // геть пам'яттю розмитих, // недоля зимний студить лоб, зажурою поритий». Часто недоля в нього асоціюється із бідою: «Не пережду я свою недолю, не перебуду свою біду». Та й лексема доля в поета переважно, як і у Т. Шевченка, вживається із епітетом зла: «Нам відпустила доля зла, // окраєць крику відпустила, // аби душа не так боліла, // щзо світ затявся дубала» [9].

Передчуття страдницької долі з'являється у віршах ще до поетового заслання: «Що буде завтра? // Дасть Бог день $і$ хліба. // А щуо, коли не буде того дня? // Тоді вже - гибій, отоді вже гибій, // простуючи до смерті навмання». Загалом поетове сприйняття долі перехрещується із поняттями дороги (дороги долі): «Дорога долі неперейдена, вилискуючи синім жалем, сховалася за ожередами», «А дякуй долі: $є$ тепер дорога // лише одна щзокроку щุовперед», "Я щче був там. Та вже моя дорога // повернення ховалася в імлі». Простежується синтез «дороги долі» і «дороги серця», які реалізуються в однойменній поезії «Дороги серця - як дороги долі...», що 
має суттєвий вплив на спрямованність життя: «Благослови ж далеку // дорогу - mу, котрої не збагнуть, // але котрою біди йдуть щзасливі, // котрою бурі й грози прогримлять» [11, с. 22]. Міфологема долі розкривається через зіставлення щзастя/нещуастя. «Не шукай дороги, посполитий, тішся тою, щуо Господь дає // Бо живі не обирають щуастя, але горе обирає нас», "Жду день при дні, та, мабуть, не діждусь // благословенного всепереймання // життя $i$ смерти, щзастя і біди» [11, с. 316].

Інші вираження міфологеми долі: тріада Богоматері-Долі-України («У всесвіті чути - голісінький голос голосить // i нас подвигає - до злетів иирянь i падінь. // Голісінький голос - чи то Богоматері, Долі, // чи то України огорнутий мороком дух»); доля-талан («Скінчився, талане? // Доле, щуе й досі стаєш на порозі?»); фатум («Що тебе клясти, моя недоле? // Не клену. Не кляв. Не проклену. // Хай життя - одне стернисте поле, // але перейти - не промину»); доля-Парка («Нема куди піти // нема куди подітись // гнітитися, гнітитись, // а долі не втекти! // По жилах час тече, // а просвітку не видко, // життя сувору нитку // проклятка Парка тче») [9, с. 228].

За гратами поета не покидає думка про втрачену свободу, неминучу ранню смерть. Поет підтверджує передбачення власної долі рядками: «Сховатися од долі-не судилось, // Ударив грім - i зразу шкереберть // пімло життя. І ось ти - все, щуо снилось // як смертнеіснування й життесмерть» [12, с. 161]. Цей же настрій поет висловлює і в рядках, де супутником смерті виступає змія: «Премудра бавиться змія, світ тихо добирає барви, // а смерть свої лаштує мари, о доле-доленько моя!» [9, с. 350].

Міфологема долі у В. Стуса близька до народного розуміння долі, про що свідчать численні бінарні опозиції фольклорного походження, а також відображення в поезії народних вірувань: «Таке - аж очі мруж! - горить 3 лабрадориту $і$ врочить долю, скриту у криці харалуж». Тому - не треба нарікати на злу долю чи недолю, а втішитися нею: «Утішся - недолею. Тим себе тіш, // щзо більше не буде ні стежки, ні кладки, // щзо ти припочаток усіх припочатків // (знова нарікаєи? Не треба, облищ!)» [9]. Подібне філософське розуміння властиве й народному світобаченню. 
Отже, міфологема долі у творчості В.Стуса перебуває у тісному зв’язку із долею самого поета й долею народу та розкривається через такі поняття: доля / недоля, щастя / нещастя, дорога, талан, фатум. Таке розуміння долі перегукується із фольклорним та Шевченковим. Перспективним постає культурологічний аналіз творчості В. Стуса в інших аспектах.

\section{ЛІТЕРАТУРА}

1. Саковець С. П. Міфопоетика поезії Василя Стуса: автореф. дис. ... канд. філол. наук: 10.01.01. Одеський національний університет ім. І.І. Мечникова. Одеса, 2012. 20 с.

2. Вишницкая Ю. В. Мифологемы Александра Блока в русском этнокультурном пространстве: дис. канд. филол. наук: спец. 10.01.02. Київ, 2006. 204 с.

3. Міфологема. URL: http://uk.wikipedia.org/wiki/Мiфологема (дата звернення: 10.01.2018).

4. Князевская Г. Б., Огуриов А.П. Судьба: метафора, идея, культура. Bопросы философии. 1992. № 7. С. 177.

5. Пилипів $O$. Репрезентація лінгвокультурного концепту «доля» в латинській фразеології. Вісник Львівського університету. Серія іноземні мови. 2013. Вип. 21. С. 226-223.

6. Зиммель Г. Проблема судьбы. Избранное: в 2 т. Москва, 1990. Т. 2. С. 199.

7. Шиенглер О. Закат Европы. Гештальт и действительность: в 2 т. Москва, 1993. Т.1. C. 274 .

8. Великий тлумачний словник сучасної української мови / укл. і гол. ред. В.Т. Бусел. Київ, Ірпінь: Перун, 2005. 1728 с.

9. Стус В. Палімпсест: Вибране [Упоряд. Д. Стус.] Київ: Факт, 2003. 432 с.

10. Дзюба I. Свіча у кам'яній пітьмі. Палімпсест. Київ: Вид-во «Факт», 2003. С. 7-32.

11. Стус B. Час творчості DICHTENSZEIT [Післямова Стуса Д.В.] Київ: Дніпро, 2005. $704 \mathrm{c}$.

12. Стус В. Дорога болю: Поезії [упоряд. та післямова Коцюбинської М.Х.]. Київ: Рад. письменник, 1990. 220 с.

\section{REFERENCES}

1. Sakovec' S. P. (2012) Mifopoetyka poeziyi Vasylya Stusa: Extended abstract of PhD dissertation (10.01.01). Odessa I.I. Mechnykov National University, Odesa. 20 p. [in Ukrainian].

2. Vyshnyckaya Yu. V. (2006) Myfolohemy Aleksandra Bloka v russkom etnokul'turnom prostranstve: $\mathrm{PhD}$ dissertation. 10.01.02. Kyiv. 204 p. [in Russian].

3. Mifolohema. URL: http://uk.wikipedia.org/wiki/Mifolohema.

4. Knyazevskaya H. B. Ohurcov A. P. (1992) Sud'ba: metafora, ydeya, kul'tura. Voprosy fylosofyy. (Vol. 7, pp. 177). [in Russian].

5. Pylypiv, O. (2013) Reprezentaciya linhvokul'turnoho konceptu «dolya» v latyns'kij frazeolohiyi. Visnyk of the Lviv University. Series foreign languages, 21, pp. 226-223. [in Russian].

6. Simmel, G. (1990) Problema sud'by. Yzbrannoe: 2 books. (Book 2. pp. 199) Moscow. [in Russian].

7. Spengler, O. (1993) Zakat Evropy. Heshtal't i dejstvytel'nost': 2 books. (Book 1. P. 274) Moscow. [in Russian].

8. Busel, V.T. (2005) Velykyj tlumachnyj slovnyk suchasnoyi ukrayins'koyi movy. 1728 p. Kyiv, Irpin': Perun. [in Ukrainian].

9. Dzyuba, I. (2003) Svicha u kam'yanij pit'mi. Palimpsest (pp.7-32). Kyiv: Fakt [in Ukrainian].

10. Stus, V. (1990) Doroha bolyu: Poeziyi [Uporyad. ta pislyamova Kocyubyns'koyi M.Kh.] (pp. 161) Kyiv: Radyanskyy pys'mennyk. [in Ukrainian]. 
11. Stus, V. (2005) Chas tvorchosti DICHTENSZEIT [Afterword Stusa D. V.] 704 p. Kyiv: Dnipro [in Ukrainian].

12. Stus, V. (2003) Palimpsest: Vybrane [Uporyad. D. Stus.] 432 p. Kyiv: Fakt [in Ukrainian].

\section{АННОТАЦИЯ}

\section{Валентина Красникова. Культурологическое осмысление мифологемы судьбы в поэзии Васыля Стуса.}

Статья содержит попытку культурологического анализа мифологемы судьбы в творчестве Васыля Стуса. Уделено внимание определению семантики слова судьба. Охарактеризованы виды, место и роль феномена мифологемы судьбы в поэзии разных периодов. Приводится сравнение понимания судьбы в творчестве Васыля Стуса, в культуре в целом, фольклоре и поэзии Тараса Шевченко.

Ключевые слова: миф, мифологема, судьба, несудьба, счастье, несчастье, фатум.

\section{ABSTRACT \\ Valentyna Krasnikova. Cultural interpretation of the mytologem of fate in the poetry of Vasyl Stus.}

The article contains an attempt to do a cultural analysis of the mythologem of fate in the works of Vasyl Stus. The article deals with the semantics of the word fate in the scientific literature and in the understanding of V. Stus. A comparative analysis of the components of this mythology in Ukrainian culture, folklore and creativity of the poet is carried out. The dynamics of development of this mythology in different periods of the poet's work was traced.

It is noted that in scientific researches of a number of humanities, one of the key concepts is the myth as the embodiment of national mentality, the original code of archetypes, symbols, meanings, representations, beliefs. At the moment, the study of the myth and myths of the artistic text, which reveals the specificity of not only the idiostyle of certain authors, but also the cultures of the people, taking into account his mythological notions, is considerably intensified. At this time, there is a noticeable shift in the emphasis on the study of Vasyl Stus's work: in the late 1990s, a complex and diverse study of the text comes into place to replace literary criticism.

The key concept of the article is the mythologeme, which is isolated in culturology as an independent author's image, built on the system of traditional cultural and literary paradigms, whose structure is formed on the ancient mythological foundations. Instead, the notion of mythologeme involves appealing to mythological plots, scenes, images that are characterized by globality and versatility. The term "mythologeme" has an ambivalent nature, in particular, it is a mythological material and a ground for creating new material.

The article emphasizes that in the traditional cultures of the past and present, fate is one of the central concepts associated with the value orientations of the personality, its religious guidelines and mentality; therefore, it appears as an object of analysis within the various sciences: philosophy, religion, literary studies, linguistics, ethics, psychology, history.

Characteristics of the types, place and role of phenomenon of mythologem of fate in the poetry of different periods was given. There was given a comparison of the understanding of fate in the works of Vasyl Stus, in the culture overall, in Taras Shevchenko's folklore and poetry.

It is determined that the mythology of the fate in the work of V. Stus is in close connection with the fate of the poet himself and the fate of the people and is revealed through such concepts: fate / disadvantage, happiness / misfortune, road, talan, fatu. This understanding of fate resounds with the vision of the problem in folklore and the works of Taras Shevchenko. Promising is the culturological analysis of Vasyl Stus's work in other aspects.

Key words: myth, mythologem, fate, misfortune, happiness, sorrow, fatum. 